\title{
DIPHENYL THIOUREA IN THE TREATMENT OF PATIENTS WITH RECURRENT LEPRA REACTIONS
}

\author{
by V. P. MaCAden, M.B., B.S. \& C.K. JOB, B.SC., M.D.,
}

Schieffelin Leprosy Research Sanatorium,

Karigiri Via Katpadi, N.A. Dt., S. India.

Although diamino-diphenyl-sulphone (DDS) is a potent antileprosy drug, there is a. significantly small percentage of leprosy patients who do not tolerate DDS. Moreover, it takes a number of years for a patient treated with DDS to become disease-arrested. Hence, the search for newer anti-leprosy drugs goes on.

Diphenyl thiourea (DPT) is one of the recent anti-leprosy drugs. It was first recognized as a chemotherapeutic agent against mycobacterium tuberculosis (MAYER, et al. 1953). Later on, it was reported that patients who developed persistent erythema nodosum leprosum with DDS, tolerated therapeutic doses of DPT with great benefit (Davey 1958, Garrod 1959). On the basis of their findings, it was decided to try out the effect of DPT on a few of our patients who were subject to frequent lepra reactions during the course of antileprosy therapy with drugs other than DPT.

\section{Material and Methods}

Four lepromatous leprosy patients from the Schieffelin Leprosy Research Sanatorium, Karigiri, who had had frequent episodes of reaction, were chosen for this trial. They were not able to take any other anti-leprosy drug in therapeutic doses even for a short time without getting a lepra reaction. The anti-leprosy drugs used were: DDS, Thiosemicarbasone, Isonicotinic acid hydrazide (INAH) together with streptomycin and sulphetrone. Thiosemicarbasone was started in doses of $25 \mathrm{mg}$. per day and gradually increased up to doses of $150 \mathrm{mg}$. three times per day. Injections of streptomycin were started in doses of $1 \mathrm{gm}$. weekly and then gradually raised to a dose of $1 \mathrm{gm}$. every day. Along with streptomycin, INAH was administered in doses of $25 \mathrm{mg}$. once a day to start with. Gradually, its dosage was raised to $100 \mathrm{mg}$. twice a day. Injections of sulphetrone $50 \%$ solution were used. The initial dose given was $0.5 \mathrm{ml}$. once a week, and the dose was gradually increased to $3 \mathrm{ml}$. twice a week. First, anti-leprosy drugs such as DDS, thiosemicarbasone, streptomycin, INAH and sulphetrone were tried in smaller doses and so long as these drugs were tolerated. On most occasions the maximum dose could not be reached because of the onset of reaction. When it was found that they could not tolerate any of the above drugs, DPT was started with a dose of $250 \mathrm{mg}$. per day and gradually increased to the maximum dose of $1,000 \mathrm{mg}$. twice a day within a period of three months. DPT was stopped as soon as signs and 
symptoms of reaction appeared and was started again soon after the reaction had subsided. Patients were considered to be in reaction if during the course of treatment they developed erythema nodosum leprosum, fever with a peak in the evening, arthralgia, particularly of the large joints like the knee, elbow and ankle and neuritis, chiefly of the ulnar, lateral popliteal and posterior tibial nerves.

A detailed history of the disease was obtained and a thorough physical examination was carried out. The frequency, duration and type of lepra reactions the patients had and the duration and the kind of previous anti-leprosy treatment were recorded. Haemoglobin percentage, routine blood counts, routine examinations of urine and stools were done initially and were repeated at regular intervals.

\section{CASE REPORTS}

Case No. 1. SLRS. 293. Male aged 35 years was first seen on 24.8.1956. He gave a history of having had leprosy for the past two years.

On examination, there were vague hypopigmented macules on the medial aspect of the thighs which were not anaesthetic to touch and had ill-defined borders. There was gross infiltration of the ear lobes, trunk and limbs. An ulcer between the 1st and 2nd toe of the right foot was also present. Red blood cell count was $4,890,000 /$ c.m.m. Haemoglobin was 12.25 grams per cent, packed cell volume (PCV) was 39 per cent. The urine showed no abnormality and the stools showed hook worm ova and whip worm ova. The bacteriological index was 3.62. For a period of 32 months and 26 days DDS, Thiosemicarbasone, Sulphetrone injections, INAH alone, INAH in combination with DDS and INAH with streptomycin were tried one after the other. These drugs could only be administered in quantities well below the therapeutic dose and only for short periods because of the onset of reactions. The total period during which he received anti-leprosy treatment in one form or other was 11 months and one day. During the regime there were seven episodes of lepra reactions, the total duration of reaction amounted to four months and six days. There was only a minimal change in the bacterial index from 3.62 to 3.00 .

On 20.5.1959, he was started on DPT. At this time his haemoglobin was $14.25 \mathrm{gm}$. percent and the total white blood cell count was $15,800 / \mathrm{c} . \mathrm{m} . \mathrm{m}$. Urine and stools showed no abnormality.

From 20.5.1959, for a period of 36 months and 20 days, DPT was given as long as he could tolerate the drug, which amounted to 32 months. During this period, too, he had lepra reaction seven times. However, the total duration the patient was in reaction was only 2 months and 19 days. The bacteriological index came down steadily from 3.00 to 1.12. Blood, urine and stools showed no abnormality.

Case 2. SLRS. 1225. A male aged 19 years reported in Schieffelin Leprosy Research Sanatorium, Marigiri, on 19.10.1956, with a history of having had leprosy for seven years. He had five years of irregular treatment with DDS. On examination, the face and trunk showed some areas of gross infiltration and on the rest of the body there was fine infiltration. Glove and stocking anaesthesia was present. All the peripheral nerve trunks were thickened.

The haemotological investigations showed haemoglobin of $9.75 \mathrm{gm}$. per cent, PCV of 36 per cent. RBC count of 5.27 million per c.m.m. The bacteriological index was 3.12. Hook worm ova were present in the stools.

He was given DDS to begin with and because of the onset of lepra reaction, it was changed to streptomycin and INAH and later on INAH in combination with thiosemicarbasone in quantities well below the therapeutic dose. Out of 26 months and 7 days of hospital case, he had reaction 9 times. The total period he was in reaction amounted to 6 months and 28 days. He was on specific treatment for 19 months and 9 days. The bacteriological index at the end of this period was 1.87 .

DPT was started on 20.5.1959. The haemoglobin was $10.25 \mathrm{gm}$. per sent. The white blood cell count was 10.800 per c.m.m. The urine showed no abnormality. During the next 18 months and 24 days, the patient tolerated DPT for 16 months and 26 days. He had three episodes of lepra reaction. The total period he was in 
reaction amounted to one month and 11 days. The bacteriological index dropped from 1.87 to 1.25 within a period of about $1 \frac{1}{2}$ years. At this point the patient discontinued treatment.

Case 3. SLRS. 1160 A male aged 20 years was seen on 24.9.1956 with a history of having had a patch on the left buttock for two years. The disease gradually spread and involved the entire body. On examination, there was gross infiltration over the face, trunk and limbs. Nodular infiltration of the ear lobes was also noticed. Examination of the cardio-vascular system revealed a rough presytolic murmur in the mitral area. Plantar ulcers were present on both feet. Examination of the lungs and abdomen did not show any abnormality. Haemoglobin was $9.00 \mathrm{~g}$. per cent, PCV 33 per cent. Hook worm ova were present in the stools. Urinalysis was done and found to be normal. The bacteriological index was 3.75. He was given injections of $50 \%$ sulphetrone, starting with an initial dose of $0.5 \mathrm{ml}$. twice weekly and gradually increased to $3 \mathrm{ml}$. twice a week. For 12 months there was no evidence of any lepra reaction. The bacteriological index fell from 3.75 to 2.75 . No anti-leprosy drug could be administered in therapeutic doses for the next 18 months because of the onset of lepra reaction. The drugs tried were: DDS, thiosemicarbasone and streptomycin in combination with INAH. Within a period of 39 months and 26 days, he had lepra reaction nine times. During this period, he had some form of anti-leprosy therapy for a total period of 22 months and 14 days. The total period during which he was in reaction amounted to 26 months and 19 days. The bacterial index during this period dropped to 1.37 .

DPT was started on 20.1.1960, when the bacterial index was 1.37. He had DPT for 13 months and 7 days without a single episode of lepra reaction. The bacterial index steadily came down from 1.37 to 0.37 . DPT was discontinued because of a relapse of the disease, viz. the appearance of new nodules showing bacilli in the form of rods.

Case 4. SLRS. Male aged 20 years was first examined on 7.12.1956, at which time he gave a history of having had leprosy for seven years. He complained of loss of voice since six months.

On physical examination, there was gross nodular infiltration of face, limbs and trunk. Heart, lungs and abdomen revealed no abnormality. His bacteriological index on 21.12.1956 was 3.87. His haemoglobin was $10 \mathrm{gm}$. per cent, total RBC $3,450,000$ per c.m.m., PCV 35 per cent. During a period of 28 months and 2 days, attempts were made to treat the patient with DDS, thiosemicarbasone, injections of sulphetrone, streptomycin and INAH. The total period during which he received some form of anti-leprosy treatment was 19 months and 27 days. But, it must be noted that at no time was the full therapeutic dose of any of the above-mentioned drugs ever reached. Sometimes, small doses of these drugs precipitated a reaction. So, all efforts to treat him with anti-leprosy drugs met with failure. During this period, he had lepra reaction nine times and the ninth attack lasted for ten months and 26 days. The total period during which he was in reaction amounted to 13 months and 22 days. The bacterial index however, came down from 3.87 to 1.62. Since no other anti-leprosy drug could be given continually in full doses without causing a lepra reaction, he was given DPT from 20.5.1959. His bacterial index on 20.5.1959 was 1.62. His white blood cell count was 18,000 per c.m.m. Haemoglobin was 9 gm. per cent. Urine showed no abnormality. During the following period of 17 months, he received effective anti-leprosy treatment for a period of 13 months and 20 days. However, he had lepra reaction seven times, the total period amounting to four months and six days only. His bacillary index fell from 1.62 to 0.37 in 17 months.

\section{Results}

As mentioned above, the treatment of these patients either with DPT or drugs other than DPT, had to be stopped with the onset of reaction. A mild reaction was ignored and treatment was continued. In assessing the value of DPT, two methods were used: (1) the 'percentage duration of treatment' and (2) the average number of days per month the patient could tolerate treatment. The 'percentage duration of treatment' was calculated as follows:

The number of months a patient was actually given DPT or drugs other than DPT, was separately added up and expressed as a 
percentage of the total period of hospital care with that particular regime.

The 'percentage duration of reaction' was calculated in a similar way. The number of days per month a patient was in reaction was

\begin{tabular}{|c|c|c|c|c|c|}
\hline $\begin{array}{l}\text { Case } \\
\text { No. }\end{array}$ & Regime & $\begin{array}{l}\text { Total period } \\
\text { of each regime } \\
\text { in months }\end{array}$ & $\begin{array}{l}\text { Duration of actual } \\
\text { treatment with } \\
\text { DPT or other anti- } \\
\text { leprosy drugs }\end{array}$ & $\begin{array}{l}\text { Percentage } \\
\text { duration of } \\
\text { treatment }\end{array}$ & $\begin{array}{l}\text { Average } \\
\text { daration of } \\
\text { treaument in } \\
\text { days/month }\end{array}$ \\
\hline \multirow{2}{*}{1} & Other drugs & $\begin{array}{l}32 \text { months } \\
\text { and } 26 \text { days }\end{array}$ & $\begin{array}{l}11 \text { months } \\
\text { and } 1 \text { day }\end{array}$ & $34.1 \%$ & 10 days \\
\hline & DPT & $\begin{array}{l}36 \text { months } \\
\text { and } 20 \text { days }\end{array}$ & 32 months & $87.2 \%$ & 26.1 days \\
\hline \multirow{2}{*}{2} & Other drugs & 31 months & $\begin{array}{l}19 \text { months } \\
\text { and } 9 \text { days }\end{array}$ & $62.2 \%$ & 18.7 days \\
\hline & DPT & $\begin{array}{l}18 \text { months } \\
\text { and } 24 \text { days }\end{array}$ & $\begin{array}{l}16 \text { months } \\
\text { and } 26 \text { days }\end{array}$ & $92.2 \%$ & 26.9 days \\
\hline \multirow{2}{*}{3} & Other drugs & $\begin{array}{l}39 \text { months } \\
\text { and } 26 \text { days }\end{array}$ & $\begin{array}{l}22 \text { months } \\
\text { and } 14 \text { days }\end{array}$ & $56.9 \%$ & 17 days \\
\hline & DPT & $\begin{array}{l}13 \text { months } \\
\text { and } 7 \text { days }\end{array}$ & $\begin{array}{l}13 \text { months } \\
\text { and } 7 \text { days }\end{array}$ & $100 \%$ & 30 days \\
\hline \multirow{2}{*}{4} & Other drugs & $\begin{array}{l}28 \text { months } \\
\text { and } 2 \text { days }\end{array}$ & $\begin{array}{l}19 \text { months } \\
\text { and } 27 \text { days }\end{array}$ & $70.9 \%$ & 21 days \\
\hline & DPT & 17 months & $\begin{array}{l}13 \text { months } \\
\text { and } 20 \text { days }\end{array}$ & $80.3 \%$ & 24 days \\
\hline
\end{tabular}

also calculated and a comparison was made between DPT and drugs other than DPT. The results are tabulated below.

\section{Duration of Treatment}

In Case No. 1, the percentage duration of treatment was $34.1 \%$ with the anti-leprosy drugs other than DPT and $87.2 \%$ with DPT. The average number of days of treatment administered per month was ten days for the other drugs and 26.1 days for DPT, viz. an increase of 16.1 days per month with DPT. Thus, DPT was significantly better tolerated than the other drugs.

In Case No. 2, with DPT the percentage duration of treatment increased from $62.2 \%$ to $92.2 \%$ and the average number of days the patient could take treatment without reaction increased from 18.7 days per month to 26.9 days per month. This is significantly more than the other drugs.

In Case No. 3, the percentage duration of treatment increased from $56.9 \%$ to $100 \%$ with DPT. Similarly, the average number of days per month the patient tolerated treatment increased from 17 days to 30 days. Thus, it would be seen that the duration of treatment with DPT was much greater than that with the other antileprosy drugs.

In Case No. 4, the increase in the percentage duration was from $70.9 \%$ with the other anti-leprosy drugs to $80.3 \%$ with DPT. 
The average number of days per month the patient could tolerate treatment increased from 21 days per month to 24 days per month. This increase is not particularly striking.

\section{Duration of Reaction}

In Case No. 1, the patient was in reaction for $12.61 \%$ of the total period of 32 months and 26 days. On an average, he was in reaction for 4 days per month. When treated with DPT, only $7.18 \%$ of the period of treatment or on an average 2.1 days per month were taken up by lepra reactions. This meant that the percentage duration of reaction was reduced by $5.43 \%$ or 1.9 days per month.

In Case No. 2, during the first 31 months when other antileprosy drugs were used, the patient was in lepra reaction for only $22.36 \%$ of this period. When DPT was substituted, he was subjected to lepra reaction for only $7.26 \%$ of the total peroid which was 18 months and 24 days. Thus, the duration of reaction with DPT was three times less than that noticed with the other anti-leprosy drugs used prior to DPT.

The above results are tabulated below in detail:

\begin{tabular}{|c|c|c|c|c|c|}
\hline $\begin{array}{l}\text { Case } \\
\text { No. }\end{array}$ & Regime & $\begin{array}{l}\text { Total period } \\
\text { of each regime } \\
\text { in months }\end{array}$ & $\begin{array}{l}\text { Total duration } \\
\text { of reaction with } \\
\text { DPT or drugs } \\
\text { other than DPT }\end{array}$ & $\begin{array}{l}\text { Percentage } \\
\text { duration of } \\
\text { reaction }\end{array}$ & $\begin{array}{c}\text { Average } \\
\text { duration } \\
\text { of reaction } \\
\text { (in days per } \\
\text { month) }\end{array}$ \\
\hline \multirow{2}{*}{1} & Other drugs & $\begin{array}{l}32 \text { months } \\
\text { and } 26 \text { days }\end{array}$ & $\begin{array}{l}4 \text { months } \\
\text { and } 6 \text { days }\end{array}$ & $12.61 \%$ & 4 days \\
\hline & DPT & $\begin{array}{l}36 \text { months } \\
\text { and } 20 \text { days }\end{array}$ & $\begin{array}{l}2 \text { months } \\
\text { and } 19 \text { days }\end{array}$ & $7.18 \%$ & 2.1 days \\
\hline \multirow{2}{*}{2} & Other drugs & 31 months & $\begin{array}{l}6 \text { months } \\
\text { and } 28 \text { days }\end{array}$ & $22.36 \%$ & 3.1 days \\
\hline & DPT & $\begin{array}{l}18 \text { months } \\
\text { and } 24 \text { days }\end{array}$ & $\begin{array}{l}1 \text { month } \\
\text { and } 11 \text { days }\end{array}$ & $7.26 \%$ & 2.1 days \\
\hline \multirow{2}{*}{3} & Other drugs & $\begin{array}{l}39 \text { months } \\
\text { and } 26 \text { days }\end{array}$ & $\begin{array}{l}26 \text { months } \\
\text { and } 19 \text { days }\end{array}$ & $80.2 \%$ & 20 days \\
\hline & DPT & $\begin{array}{l}13 \text { months } \\
\text { and } 7 \text { days }\end{array}$ & NIL & NIL & NIL \\
\hline \multirow{2}{*}{4} & Other drugs & $\begin{array}{l}28 \text { months } \\
\text { and } 2 \text { days }\end{array}$ & $\begin{array}{l}13 \text { months } \\
\text { and } 22 \text { days }\end{array}$ & $48.93 \%$ & 14.7 days \\
\hline & DPT & 17 months & $\begin{array}{l}4 \text { months } \\
\text { and } 6 \text { days }\end{array}$ & $24.7 \%$ & 7 days \\
\hline
\end{tabular}

Case No. 3 with the other anti-leprosy drugs was in reaction for $80.2 \%$ of 39 months and 26 days. This meant that on an average 
the patient was in reaction for 20 days per month whereas on DPT the patient was not subject to even a single episode of lepra reaction. This was a significant advantage over the other drugs.

In Case No. 4, the percentage duration of reaction was $48.93 \%$ of the total period of 28 months and 22 days with the drugs other than DPT, viz. an average of 14.1 days per month. On the other hand, with DPT, the same patient was in lepra reaction only for $24.70 \%$ of a period of 17 months, an average of 7 days per month. Thus, the duration of reaction was halved with DPT.

Improvement in the bacterial index:

The average fall of B.I. in indices per year was calculated and tabulated as follows:

Average Fall in Bacterial Index Per Year

\begin{tabular}{l|c|c|c|c} 
& Case 1 & Case 2 & Case 3 & Case 4 \\
\hline During the phase prior to DPT & 0.23 & 0.48 & 0.79 & 0.96 \\
\hline During the phase of DPT & 0.60 & 0.39 & 0.92 & 0.88
\end{tabular}

A review of the above results will show that the improvement in the bacterial index was better with DPT in Cases 1 and 3. The other cases did not show a result that was better than the other antileprosy drugs.

\section{Severity of Reactions}

There was no difference in the severity of each episode of reaction, viz. the degree of fever, erythema nodosum or neuritis.

\section{Comments:}

DAveY, T. F., in 1958, reported the beneficial effects of DPT on seven cases of lepromatous leprosy who were subject to persistent erythema nodosum. They were able to tolerate therapeutic doses of DPT. GARROD, J. M. B., in 1959, reported that 11 out of 33 patients tolerated DPT with less reaction and also showed improvement clinically. Kıм, J. S. and Topple, S. C., in 1962, reported that a third of the 33 patients who were subjected to lepra reaction with DDS tolerated DPT without being subjected to lepra reaction.

\section{Summary}

In this study of four cases of lepromatous leprosy with recurrent reactions it was seen that the advantages of DPT were that:

1. The number of days the patient was in reaction was very much less than that with the other drugs. So, it is reasonable to assume that all the consequences of reactions such as the duration of hospitalization, pain and discomfort to the patient and the incidence of deformity may be less.

2. The number of days the patient could be subject to anti-leprosy treatment with this drug were more than the other drugs.

In this connection, it must also be noted that:

1. During treatment with DPT no particular advantage in the 
rate of fall of the bacterial index over the other drugs was seen.

2. The severity of each reaction when it occurred in the DPT regime appeared to be the same as the other drugs.

3. Although during certain periods sub-therapeutic doses of anti-leprosy drugs were used in these patients, a fall in bacterial index was noticed. The number of cases studied is small. The extreme variability of a patient's susceptibility to reactions from year to year has not been taken into account. DPT seems the best available treatment in cases of recurrent or persistent reactions.

\section{Acknowledgement}

We are most grateful to Ciba Pharma Private Ltd. for supplying us with the necessary quantities of diphenyl thiourea for this trial.

\section{References}

Davey, T. F., Lep. Review (1958) 29:31-32.

Garrod, J. M. B., Lep. Review (1959) 30:4.

Kim, J. S. and Topple, S. C., Lep.Review (1962) 33:20-24.

Mayer, R. L., Eisman, P. C. and Konopka, E. A. as quoted by Davey, T. F., Lep. Review' (1956) 27:94.

Davey, T. F., Lep. Review (1956) $27: 94$ and 103. 